\title{
The Capability of Pronouncing the English Diphthongs by the English Department Students, Faculty of Humanities, Udayana University
}

\author{
Ni Luh Ketut Mas Indrawati ${ }^{1}$, Ida Ayu Made Puspani \\ ${ }^{1,2}$ Faculty of Humanities Udayana University Bali Indonesia
}

\begin{abstract}
This study aims at investigating the capability of the English department students, Faculty of Humanities, Udayana University in pronouncing diphthongs. Diphthong is a glide from one vowel to another. English is very rich in words containing diphthongs, such as: / aI / in the word try / traI / buy / baI /; / eI /, in the words they / deI /, day / deI /, / eə / as in hair / heə /, chair /t $\mathrm{fe} /$. Meanwhile, the number of diphthongs in Indonesian and Balinese as the mother tongue of the students is very limited. This difference certainly creates problems for students in pronouncing the English words consisting of diphthongs.

The knowledge of English sounds is taught in the subject of English phonetics and phonemics in the fifth semester. This study examined the ability of new students who have not taken the English Phonetics and Phonemics subject to be compared with the ability of those who have got this subject, so that it can be seen to what extent this course can change student performance in pronouncing diphthongs.

This research is a qualitative descriptive research supported by quantitative data. The population of this study was 50 new students and 50 sixth semester students, taken randomly. The research instrument was a list of English words containing diphthongs and questionnaires. The technique of collecting data was done through recording, and the data were analyzed descriptive qualitatively and presented formally and informally.
\end{abstract}

KEYWORDS: Capability, English Diphthongs, Phonetics, Phonemics, Pronunciation

\section{INTRODUCTION}

The English Department Faculty of Humanities, Udayana University has challenging tasks and responsibilities in order to produce prospective graduates. Graduates from the English Department are expected to have good academic and non-academic abilities. The Graduates are targeted to understand the English system (grammar, phonology, morphology, semantics, syntax), understand the principles of learning, and have proficiency in using English to communicate.

Many experts state that English pronunciation is one of the most difficult skills to acquire and learners should spend a lot of time improving pronunciation. Gilakjani (2012) argues that correct pronunciation is one of the main requirements for the competence of the learners. According to Yates and Zielinski (2009), great attention to English pronunciation shows that pronunciation has a key role in learning English. If the general principles and principles towards comprehensive pronunciation are not taught, the learner will not be able to do it well. One of the compulsory subjects that is closely related to the English pronunciation, in the English Department is the English Phonetics and Phonemics. This course is given to the English students in the 5th semester, and has a weight of 3 credit points. The purpose of giving this course is to provide an understanding of the theoretical sound system of English, which can later be applied to improve English pronunciation in speaking skills. Learners are often considered as the main factor in the success of pronunciation in language. It has been acknowledging that adult learners (adult learner) will have difficulty in pronouncing foreign languages because they get used to pronouncing their mother tongue that they use every day. The organs of speech (the articulators) of every adult learner have been accustomed to pronouncing sounds in words or sentences in the mother tongue.

Cook (1996 as quoted by Pourhose in Gilakjani, 2016) defines pronunciation as the production of the English sounds. Pronunciation is learned by repeating sounds and correcting them if they are pronounced incorrectly. When learners start learning pronunciation, they create new habits and adjust the difficulties that come from their mother tongue. Pronunciations of the English diphthongs are generally problems for students at the English Department, Faculty of Humanities, Udayana University, who mainly speak Balinese or Indonesian. This is due to differences in the sound system of English and Balinese or Indonesian. English has eight diphthongs, namely: / aI /, / a /, / eI /, / ə৩ /, / Iə /, / eə /, / ə / and / ○I /, and English words contain lots of diphthongs. 


\section{International Journal of Current Science Research and Review}

ISSN: 2581-8341

Volume 04 Issue 05 May 2021

DOI: 10.47191/ijcsrr/V4-i5-11, Impact Factor: 5.825

Indonesian only has three diphtongs (/ aI /, / av /, and / oI /, and the number of words consisting of diphthongs is very limited. Meanwhile, Balinese language is said to have no diphthongs at all. This is what attracts researchers for examining the capability of the English students in the English Department, Faculty of Humanities, Udayana University in pronouncing the English diphthongs. The aims of this article are: to describe the capabilities of new and the 6th semester students in the English Department, Faculty of Humanities, Udayana University in pronouncing English diphthongs; to analyze to what extent the English phonetics and phonemics subject affect the English diphthong pronunciation of the English students.

Based on the description of the background of the study there are two research questions discussed in this study: (1) How are the capability of the new and the $6^{\text {th }}$ semester students in pronouncing English diphthongs, and (2) How is the effect of the English phonetics and phonemics subject to the students in pronouncing English diphthongs?

\section{LITERARY REVIEW}

Gilakjani (2016) in the International Journal of Research in English Education wrote an article on the topic English Pronunciation Instruction: A Literature Review. He revealed the difficulty of English pronunciation instruction was due to several reasons such as: the absence of clear guidelines for teachers so that teachers are faced with conflicting exercises regarding pronunciation instruction and the absence of a systematic method to determine what to teach, when, and how to do it so that teachers do not feel comfortable teaching pronunciation in class. In his article he reviewed several important issues regarding pronunciation instruction with the aim of defining pronunciation terms, assessing the objectives of pronunciation instruction, explaining the importance of pronunciation instruction, explaining the role of teachers in teaching pronunciation and providing some ideas in helping teachers improve learners' pronunciation. This literature review showed that if teachers were to teach pronunciation accurately, they had to be trained in pronunciation instruction.

Nafisah Endahati (2014) examined the improvement of the Pronunciation Ability of Class A1 students in Semester I of the 2013/2014 FKIP UPYTA, English Education Program through the audio-lingual approach by applying collaborative and participatory classroom action research methods. The results of her research showed that an audio-lingual approach with pronunciation training techniques in learning can improve the English pronunciation capabilities. This could be indicated by the increased accuracy of students' pronunciation in all aspects of sounds in English, the stress of syllables in vocabulary, and the intonation in sentences. The improvement of speaking skills in the English class was also supported by the results of the absorption of understanding of pronunciation skills in English with a percentage value of $63.33 \%$ (cycle I), $73.33 \%$ (cycle II), and 80\% (cycle III).

Roach (1983: 19) defines diphthong as a shift from one vowel to another. Vowels that do not experience a movement or glide are called pure vowels, and one of the common pronunciation errors for English learners is to replace the diphthongs by pure vowels. Roach (1983: 19) groups the English diphthongs as described in the following diagram:

\section{DIPHTHONG}

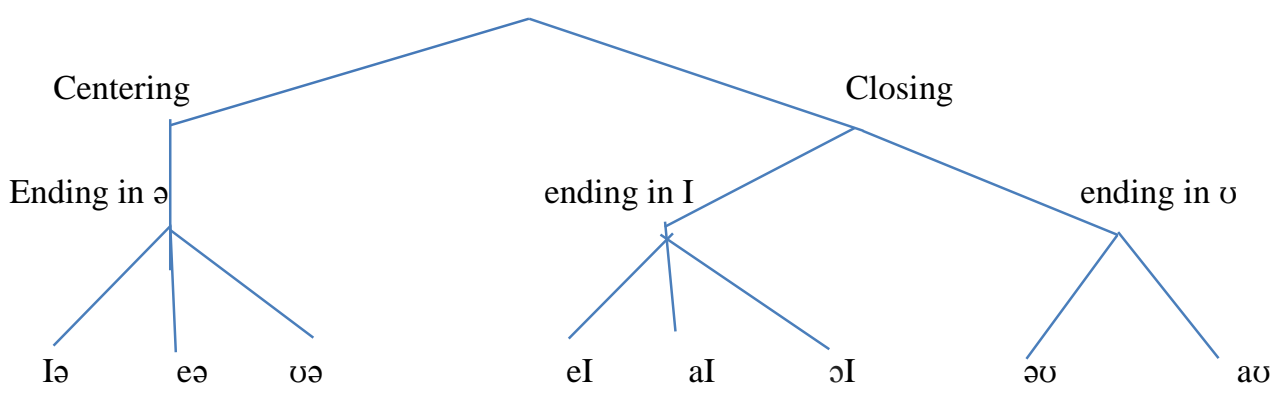




\section{International Journal of Current Science Research and Review}

ISSN: 2581-8341

Volume 04 Issue 05 May 2021

DOI: 10.47191/ijcsrr/V4-i5-11, Impact Factor: 5.825

IJCSRR@ 2021

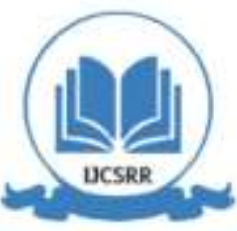

Www.ijcsrr.org

Kelly (2000: 34) states that a simple definition of a diphthong is a combination of vowel sounds. He adds that there is a movement from one pure vowel to another and the first vowel sound is longer and louder, but not for all languages. This is what causes frequent mispronunciation of English learners. Similar to Roach, Kelly claims that there are eight vowels in the English language. Kelly (2000: 37) states that the purpose of discussing sounds separately in the class is to help learners pronounce certain sounds or phonemes that have an impact on speaker's communication and understanding. Katamba (1989: 12) defines diphthong as a vowel sound that changes in quality when pronounced. He considers a single vowel sound as a vowel sound whose quality does not change in the duration of the pronunciation.

\section{METHODOLOGY}

This research is a descriptive qualitative research. The data obtained were qualitative in nature supported by quantitative data. The population of this research was new students and students from the sixth semester in the English Department, Faculty of Humanities, Udayana University. 75 new students and 75 sixth semester students were randomly taken as the samples of this research. Most of the respondents speak Indonesian and some speak Balinese as their mother tongues. The data were taken from the results of the recording of the pronunciation of 40 English words containing eight types of diphthongs, and the results of the questionnaires distributed to 150 respondents from both groups. The data that had been collected were presented in the form of graph and were analyzed in a descriptive-qualitative manner based on the phonological theory by Roach (1983) and Kelly (2003).

\section{RESULT AND DISCUSSION}

\subsection{The Ability of New Students in pronouncing the English diphthongs}

The results of the recording of the pronunciation of 40 English words containing the eight types of diphthongs by 75 new semester students were carefully observed and transcribed phonemically to identify whether the pronunciation was correct or wrong. Then the individual scores for this group were determined, the score was obtained from the number of words that were correctly pronounced divided by the number of words (40), multiplied by 100 . The total scores for the 75 students were then divided by 75 (the number of students) so that the average score for this group was obtained, namely 65, 16. (See Table.1)

Table 1. Capability in pronouncing diphthong by new students in the English Department.

\begin{tabular}{|c|c|c|c|c|c|c|c|c|}
\hline $\begin{array}{l}\text { SS. } \\
\text { number. }\end{array}$ & $\begin{array}{l}\text { Correct } \\
\text { number }\end{array}$ & score & $\begin{array}{l}\text { SS. } \\
\text { number. }\end{array}$ & $\begin{array}{l}\text { Correct } \\
\text { number }\end{array}$ & score & SS. number & $\begin{array}{l}\text { Correct } \\
\text { number }\end{array}$ & score \\
\hline 1 & 18 & 45 & 26 & 25 & 63 & 51 & 31 & 78 \\
\hline 2 & 20 & 50 & 27 & 24 & 60 & 52 & 25 & 63 \\
\hline 3 & 31 & 78 & 28 & 31 & 78 & 53 & 34 & 85 \\
\hline 4 & 29 & 73 & 29 & 27 & 68 & 54 & 24 & 60 \\
\hline 5 & 30 & 75 & 30 & 31 & 78 & 55 & 24 & 60 \\
\hline 6 & 25 & 63 & 31 & 25 & 63 & 56 & 28 & 70 \\
\hline 7 & 24 & 60 & 32 & 34 & 85 & 57 & 20 & 50 \\
\hline 8 & 31 & 78 & 33 & 24 & 60 & 58 & 29 & 73 \\
\hline 9 & 27 & 68 & 34 & 24 & 60 & 59 & 27 & 68 \\
\hline 10 & 31 & 78 & 35 & 28 & 70 & 60 & 21 & 53 \\
\hline 11 & 25 & 63 & 36 & 18 & 45 & 61 & 23 & 58 \\
\hline 12 & 34 & 85 & 37 & 20 & 50 & 62 & 27 & 68 \\
\hline 13 & 24 & 60 & 38 & 31 & 78 & 63 & 22 & 55 \\
\hline 14 & 24 & 60 & 39 & 29 & 73 & 64 & 32 & 80 \\
\hline 15 & 28 & 70 & 40 & 30 & 75 & 65 & 21 & 53 \\
\hline 16 & 20 & 50 & 41 & 27 & 68 & 66 & 26 & 65 \\
\hline 17 & 29 & 73 & 42 & 22 & 55 & 67 & 18 & 45 \\
\hline 18 & 27 & 68 & 43 & 32 & 80 & 68 & 20 & 50 \\
\hline
\end{tabular}




\section{International Journal of Current Science Research and Review}

ISSN: 2581-8341

Volume 04 Issue 05 May 2021

DOI: 10.47191/ijesrr/V4-i5-11, Impact Factor: 5.825

IJCSRR@ 2021

www.ijesrr.org

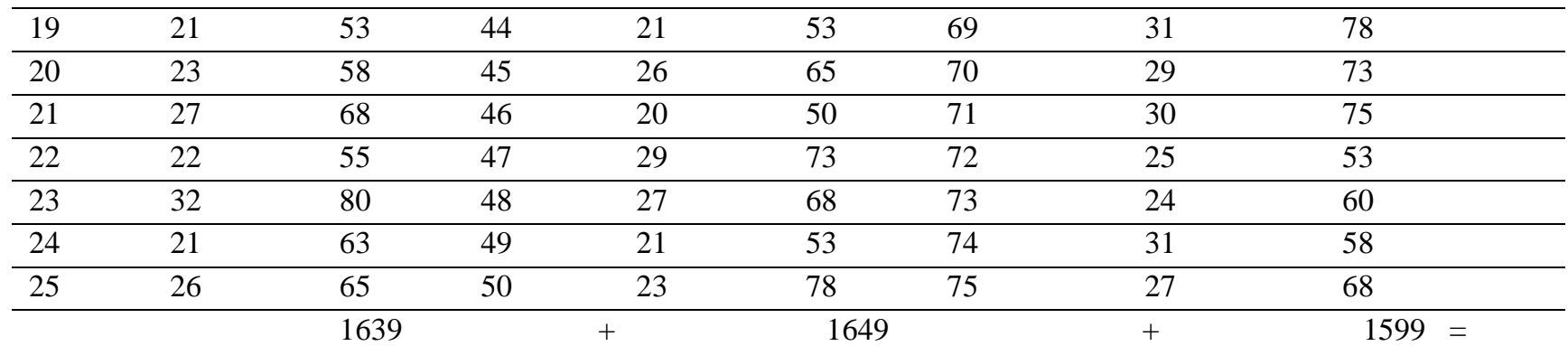

4887: $75=65,16$

Average 65,16

The words containing diphthongs that were problematic for the students were examined and identified as in Table 2 . Table 2 shows that the New Students of the English Department, Faculty of Humanities, Udayana University had problems in pronouncing most of the English diphthongs. Even for the English words that contain diphthongs which are similar to those found in Indonesian such as / aI /, in the words; life and file, some of the students in this group still pronounced them incorrectly, 5 students (7\%) pronounced it with / I / (ie; / IIf /, / fIl /), and diphthong, / av / as in loud, proud, they still had problems in pronouncing them (loud and proud should be pronounced / laød / and / praød / were pronounced as / l $v \mathrm{~d} / \mathrm{and} / \mathrm{pr} \sigma \mathrm{d} /$, as many as 50 students (67\% of them) pronounced it with a short vowel / $/$. Only diphthong / oI / which can be pronounced correctly by the 75 (100\%) students. The distribution of diphthong pronunciations by the new students can be seen in Table 2.

Table 2. The distribution of diphthong pronunciation by the new students

\begin{tabular}{|c|c|c|c|c|c|}
\hline Diphthong & $\begin{array}{l}\text { The number of } \\
\text { students } \\
\text { mispronounced } \\
\text { diphthong }\end{array}$ & percentage & $\begin{array}{l}\text { The number of } \\
\text { students } \\
\text { pronounced } \\
\text { diphthong } \\
\text { correctly }\end{array}$ & percentage & $\begin{array}{l}\text { Sounds used } \\
\text { to replace the } \\
\text { diphthongs }\end{array}$ \\
\hline 1. /Іа/ & 35 & $47 \%$ & 40 & $53 \%$ & $/ \mathrm{I} /$ \\
\hline 2. /eə/ & 65 & $87 \%$ & 10 & $13 \%$ & /e/ \\
\hline 3. /రə/ & 70 & $93 \%$ & 5 & $7 \%$ & $/ 0 /$ \\
\hline 4. /oI/ & - & $0 \%$ & 75 & $100 \%$ & - \\
\hline 5. /aI/ & 5 & $7 \%$ & 70 & $93 \%$ & $/ \mathrm{I} /$ \\
\hline 6. /eI/ & 72 & $96 \%$ & 3 & $4 \%$ & $/ \mathrm{I} /$ \\
\hline 7. /aø/ & 50 & $67 \%$ & 25 & $33 \%$ & $/ \mho /$ \\
\hline 8. /əठ/ & 73 & $97 \%$ & 2 & $3 \%$ & /o/ \\
\hline
\end{tabular}

Of the eight types of English diphthongs, the most problematic ones for these students ware / əv /, namely 73 people (97\%), followed by / eI / namely 72 (96\%), / və / namely 70 (93\%), / eə / namely 65 (87\%), and / Iə / 35 (47\%). In pronouncing these diphthongs, they tended to replace them with the closest short vowels, such as the words role / rəol /, phone / fəon /, which tended to be pronounced as / rol / and / fon /.

This was not in accordance with the results of the questionnaires, namely 57 (76\%) students stated that they had no difficulty in pronouncing the words on the list and were sure of their pronunciation, as many as 18 students (24\%) said it was rather difficult and only 10 people (13\%) said they were somewhat confident about the pronunciation of the words on the word list. 43 people (57\%) said they had never been taught about diphthongs in English, 20 students (27\%) said they did not remember, and only 12 (16\%) said they had been taught about diphthongs in English. This showed that they did not have enough practice to pronounce English 


\section{International Journal of Current Science Research and Review}

ISSN: 2581-8341

Volume 04 Issue 05 May 2021

DOI: 10.47191/ijcsrr/V4-i5-11, Impact Factor: 5.825

IJCSRR@ 2021

WwW.ijcsrr.org

diphthongs in the English lessons. Meanwhile, phonemically, these diphthongs showed a great difference between English studied as the foreign language and Indonesian as the mother tongue. The greater the number of language phonemes / sounds possessed by the language being studied compared to the sounds / phonemes possessed by the native language of the speaker, the more difficult it is for the learners to reach a level similar to a native speaker of the language being learned, so that it requires more practice to be able to pronounce them correctly.

\subsection{The Ability of the Sixth Semester Students in pronouncing the English diphthongs}

The recording of the pronunciation of 40 English words containing the eight types of dipthongs by 75 sixth semester students was repeatedly listened to and transcribed phonemically to determine whether the pronunciation was correct or incorrect. Then the individual scores for this group were determined, which was obtained from the number of words that were pronounced correctly divided by the number of words (40) multiplied by 100. The total scores for the 75 students were then divided by 75 (the number of students) so that the average score for this group was 85, 56. (See Table.3).

Table 3. The ability of double vowel pronunciation in English by sixth semester students.

\begin{tabular}{|c|c|c|c|c|c|c|c|c|}
\hline $\begin{array}{l}\text { SS. } \\
\text { number }\end{array}$ & $\begin{array}{l}\text { Correct } \\
\text { number }\end{array}$ & score & $\begin{array}{l}\text { SS. } \\
\text { number }\end{array}$ & $\begin{array}{l}\text { Correct } \\
\text { number }\end{array}$ & score & $\begin{array}{l}\text { SS. } \\
\text { number }\end{array}$ & $\begin{array}{l}\text { Correct } \\
\text { number }\end{array}$ & score \\
\hline 1 & 34 & 85 & 26 & 31 & 77 & 51 & 36 & 90 \\
\hline 2 & 35 & 87 & 27 & 36 & 90 & 52 & 34 & 85 \\
\hline 3 & 36 & 90 & 28 & 33 & 83 & 53 & 36 & 90 \\
\hline 4 & 32 & 80 & 29 & 36 & 90 & 54 & 33 & 83 \\
\hline 5 & 35 & 87 & 30 & 32 & 80 & 55 & 35 & 87 \\
\hline 6 & 37 & 93 & 31 & 34 & 85 & 56 & 34 & 85 \\
\hline 7 & 36 & 90 & 32 & 35 & 87 & 57 & 35 & 87 \\
\hline 8 & 32 & 80 & 33 & 34 & 85 & 58 & 36 & 90 \\
\hline 9 & 37 & 93 & 34 & 35 & 87 & 59 & 32 & 80 \\
\hline 10 & 30 & 75 & 35 & 32 & 80 & 60 & 35 & 87 \\
\hline 11 & 31 & 77 & 36 & 34 & 85 & 61 & 37 & 93 \\
\hline 12 & 36 & 90 & 37 & 35 & 87 & 62 & 36 & 90 \\
\hline 13 & 33 & 83 & 38 & 36 & 90 & 63 & 32 & 80 \\
\hline 14 & 36 & 90 & 39 & 32 & 80 & 64 & 37 & 93 \\
\hline 15 & 32 & 80 & 40 & 35 & 87 & 65 & 30 & 75 \\
\hline 16 & 34 & 85 & 41 & 37 & 93 & 66 & 31 & 77 \\
\hline 17 & 35 & 87 & 42 & 36 & 90 & 67 & 36 & 90 \\
\hline 18 & 34 & 85 & 43 & 32 & 80 & 68 & 33 & 83 \\
\hline 19 & 35 & 87 & 44 & 37 & 93 & 69 & 36 & 90 \\
\hline 20 & 32 & 80 & 45 & 30 & 90 & 70 & 32 & 80 \\
\hline 21 & 36 & 90 & 46 & 36 & 90 & 71 & 34 & 85 \\
\hline 22 & 34 & 85 & 47 & 34 & 85 & 72 & 35 & 87 \\
\hline 23 & 36 & 75 & 48 & 36 & 90 & 73 & 34 & 85 \\
\hline 24 & 33 & 83 & 49 & 33 & 83 & 74 & 35 & 87 \\
\hline \multirow[t]{2}{*}{25} & 35 & 87 & 50 & 35 & 87 & 75 & 32 & 80 \\
\hline & & $\begin{array}{l}2124 \\
6417:\end{array}$ & 85,56 & + & 2154 & & + & $2139=6417$ \\
\hline
\end{tabular}

The average score of this group is much higher than the previous group, namely the new students, this is natural because besides they had been studying English for a longer time, they had also taken the subject, English Phonetics and Phonemics in the 


\section{International Journal of Current Science Research and Review}

ISSN: 2581-8341

Volume 04 Issue 05 May 2021

DOI: 10.47191/ijcsrr/V4-i5-11, Impact Factor: 5.825

IJCSRR @ 2021

Www.ijcsrr.org

previous semester, the fifth semester. Even though they had already had this course, they still had difficulties in pronouncing certain diphthongs. This is because most of the diphthongs do not occur in Indonesian or Balinese as the mother tongue of the students. The descriptions of diphthongs which were still pronounced incorrectly by the sixth semester students were presented in Table. 4 below.

Table 4. Description of the mispronunciation of words containing diphthongs by the sixth semester students

\begin{tabular}{|c|c|c|c|}
\hline Diphthong & $\begin{array}{l}\text { The number of SS } \\
\text { mispronounced } \\
\text { Diphthongs }\end{array}$ & $\begin{array}{l}\text { The number of SS mispronounced } \\
\text { Diphthongs in percentage }\end{array}$ & $\begin{array}{l}\text { Sounds used to replace } \\
\text { dipthongs }\end{array}$ \\
\hline \multicolumn{4}{|l|}{ /əठ/ } \\
\hline 1. role & 12 & 16 & U \\
\hline 2. bone & 18 & 24 & v \\
\hline 3. phone & 15 & 20 & v \\
\hline 4. stone & 6 & 8 & v \\
\hline 5. close & 3 & 4 & v \\
\hline \multicolumn{4}{|l|}{ /Іә/ } \\
\hline 1. hear & 3 & 4 & $\mathrm{e}$ \\
\hline 2. steer & & & \\
\hline 3. clear & & & \\
\hline 4. fear & 6 & 8 & $\mathrm{e}$ \\
\hline 5. ear & & & \\
\hline \multicolumn{4}{|l|}{ /ea/ } \\
\hline 1. bear & 57 & 76 & $\mathrm{e}$ \\
\hline 2. hair & 66 & 88 & $\mathrm{e}$ \\
\hline 3. fair & 63 & 84 & $\mathrm{e}$ \\
\hline 4. stairs & 33 & 44 & e \\
\hline 5. pair & 39 & 52 & e \\
\hline \multicolumn{4}{|l|}{ /๘ə/ } \\
\hline 1. poor & 12 & 16 & v \\
\hline 2. sure & 6 & 8 & $\mho$ \\
\hline 3. tour & 39 & 52 & $\mho \supset$ \\
\hline 4. moor & 27 & 36 & $\mho$ \\
\hline 5. cure & & & \\
\hline
\end{tabular}

From the distribution of mispronunciation of words containing diphthongs by sixth semester students, it can be said that the most problematic diphthong is diphthong / eə /. a number of 66 people (88\%) students could not pronounce the word hair / heə / correctly. A total of 63 students (84\%) mispronounced the word fair / feə/, 57 students (76\%) mispronounced the word bear / beə/, 39 (52\%) mispronounced the word pair / peə / and 33 students (44\%) had problems in pronouncing the word stairs / steəs /.

The second hardest diphthong for the sixth semester students is diphthong / və /; 39 (52\%) mispronounced the word tour / tuə/, 27 (36\%) mispronounced the word moor / moə/, 12 (16\%) mispronounced the word poor, and 6 (8\%) mispronounced the word sure /

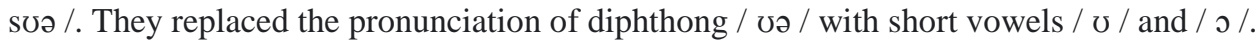

The third hardest diphthong for sixth semester students is diphthong / əv /; 18 (24\%) mispronounced bone / bəun /, 15 (20\%) mispronounced phone / foun /, 12 (16\%) mispronounced role / rəol /, 6 (8\%) mispronounced stone / stəon /, and 3 (4\%) mispronounced the word close / kləus /. They replace the pronunciation of double vowels / və / with short vowels / $\mathrm{/} \mathrm{and} \mathrm{/} \mathrm{/.}$

The last most difficult diphthong for the sixth semester students is diphthong / Iə /; 3 students (4\%) mispronounced the word here / hIə /, 6 people (8\%) mispronounced the word fear / fIə /, they replaced the pronunciation of this diphthong with a short vowel / e /.It can be said that diphthong / ai /, / av /, and / oI / can be pronounced easily because these sounds occur in Indonesian. Even though 


\section{International Journal of Current Science Research and Review}

ISSN: 2581-8341

Volume 04 Issue 05 May 2021

DOI: 10.47191/ijcsrr/V4-i5-11, Impact Factor: 5.825

IJCSRR@ 2021

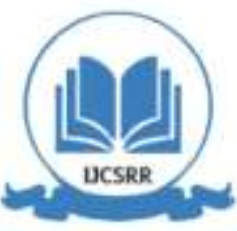

Www.ijcsrr.org

the sixth semester students have taken English Phonetics and Phonemics course, they still had difficulty in pronouncing certain diphthongs because these sounds are difficult to pronounce and require more practice.

\subsection{The Role of English Phonetics and Phonemics Subjects in Pronunciation Ability}

The English phonetics and phonemics course is a compulsory subject which is given in the fifth semester in the English Department. This course enables students to describe English sounds, apply sound symbols to transcribe English words, phrases and sentences phonetically and phonemically, apply English phonetic theory and phonology in their pronunciation in speaking.

The aim of the English phonetics and phonemics course is to improve students' English pronunciation in speaking skills by applying the English sound theory which includes language sounds including: vowel sounds, diphthongs, consonants, stress patterns and intonation.

Diphthong in English is one of the topics in this course. This topic is given after students are introduced to understand the speech sounds, which are divided into vowels and consonants. Then proceed with the introduction of a vowel sound in English which is divided into short vowels and long vowels, so that the number of vowels in English is much greater than the number of vowels in Indonesian and Balinese as the mother tongue of students.

The difference in the number of vowels possessed by English as the language studied with Indonesian and Balinese as the mother tongue is very significant, which certainly requires more efforts from students to be able to master them. Short vowels such as / I /, / e /, / o /, / /, / o/, / / / and long vowels: / i: /, / u: /, / o: /, / a: /, / 3: / are of different phonemes in English so that mispronunciation can lead to misunderstanding in communication as well as diphthong. Of the eight diphthongs in English, only three resemble diphthongs in the students' mother tongues, so in the English phonetics and phonemics course this needs to be emphasized so that students need to be given more opportunities to practice pronouncing these sounds.

The average scores of the second semester and sixth semester students showed a significant difference, namely; 65.16 (for the second semester) and 85.56 (for the sixth semester) indicate that English phonetics and phonemics have a significant role in improving student achievement in English diphthong pronunciation. This is reinforced by the results of questionnaires from respondents, namely $70(93,33 \%)$ said that they knew the words they spoke containing diphthong and $100 \%$ said they studied them in the English phonetics and phonemics course and this course helped them with diphthong pronunciation. As many as $82,66 \%$ of the respondents said that they got sufficient practice in the pronunciation of the diphthongs, but $65.33 \%$ said errors in the pronunciation of several diphthongs occurred because the diphthong sound was difficult to pronounce, $13.33 \%$ said that it was difficult because of their unfamiliar with the spelling, $8 \%$ said it was difficult because of the sound and the spelling, $8 \%$ said they had never heard the words and 5.33\% did not answer. The distribution of the pronunciation errors can be seen in graph. 1 below

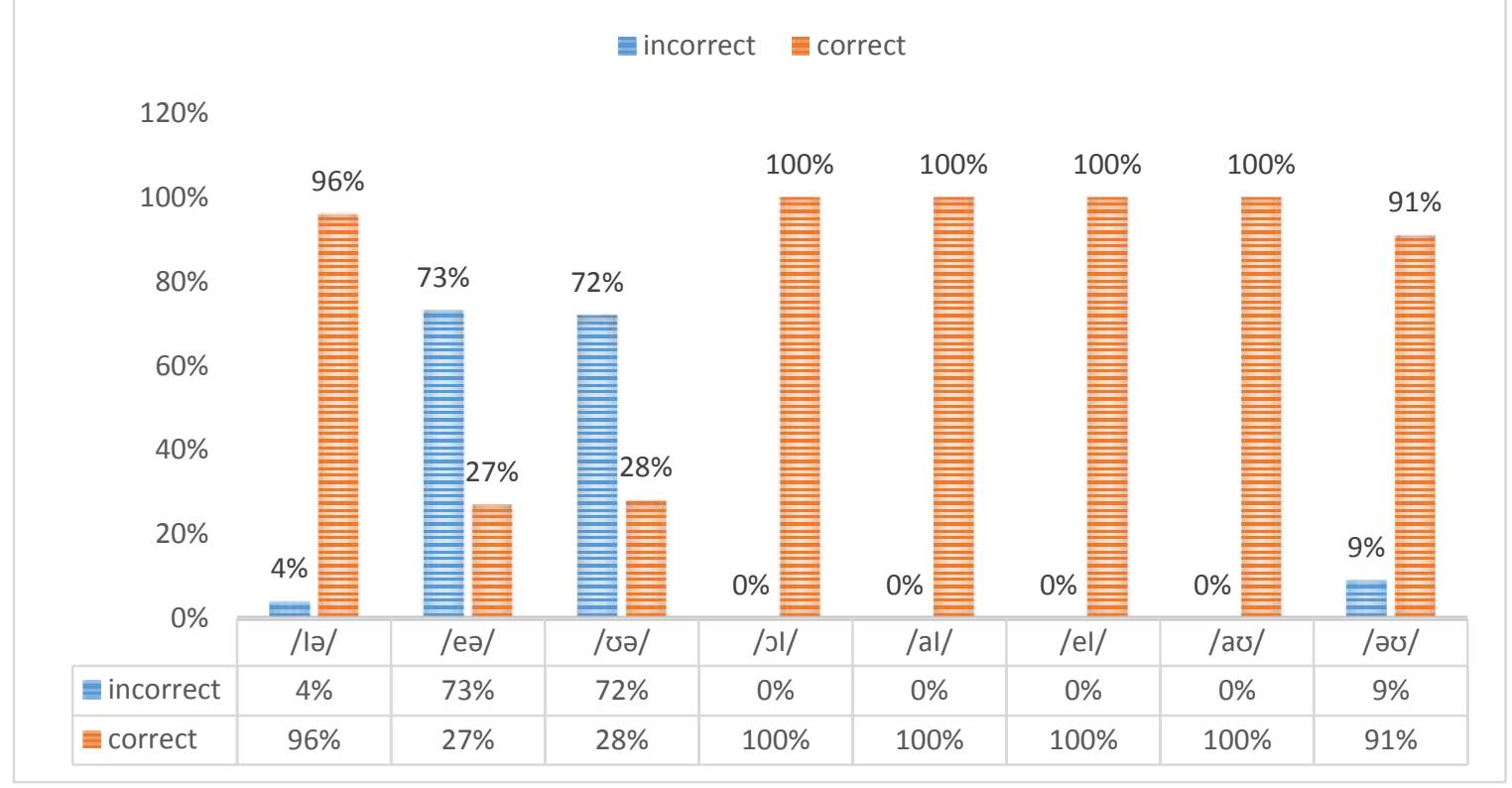

Figure 1. The destributions of diphthong pronunciation by the sixth semester students 


\section{International Journal of Current Science Research and Review}

ISSN: 2581-8341

Volume 04 Issue 05 May 2021

DOI: 10.47191/ijcsrr/V4-i5-11, Impact Factor: 5.825

IJCSRR@ 2021

WWw.ijesrr.org

English phonetics and phonemics course, still made mistakes in the pronunciation of diphthong / eə / (73\%) and / və / (72\%), and a small proportion of them still mispronounced / Iə / (4\%) and / əひ / (9\%). This shows that in teaching English phonetics and phonemics courses, students should be given more opportunities to practice pronouncing words containing diphthong.

\section{CONCLUSION}

From the data analysis regarding the ability of English diphthong pronunciation by new students and students from the sixth semester in the English Department, Faculty of Humanities, Udayana University in this study, it can be concluded as follows:

The average score of diphthong pronunciation in English by new semester students was sufficient, namely 65.16, there were still many vowels that are difficult to be pronounced by some respondents. As many as 7 (87.5\%) of the 8 types of diphthongs in English

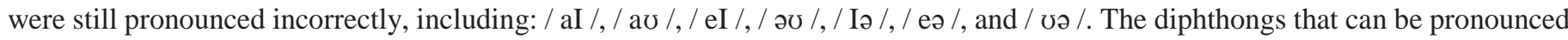
correctly by all respondents is /aI /. The pronunciation problems were due to their lack of understanding of diphthong, and also the spelling of words in English which they had not mastered properly, so that even for the diphthong resembles the diphthong in their mother tongue, they still mispronounced them.

The average ability of sixth semester students in pronouncing diphthongs in English could be considered high, namely 85.56. Some 4 (50\%) of the types of English diphthongs that were still difficult to pronounce by some respondents included: / əv /, / Iə /, / eə /, and / $ə$ /. Diphthongs that could be pronounced correctly by all respondents were / $\mathrm{oI} /, / \mathrm{aI} /$, / av /, and / eI /, this was because they already had an understanding of diphthong, and also studied English longer so they could recognize the types of words containing diphthongs. Although there were still some English diphthongs which were still difficult to be pronounced by a small number of respondents because these diphthongs require intensive practice to pronounce them correctly.

The English phonetics and phonemics course had played a very important role in improving diphthong pronunciation of the English Department students, this was evidenced by a significant difference from the average value of the two groups of respondents, and the results of the questionnaires from the group that had taken this course showed that they (semester six) were helped a lot in pronouncing diphthongs from the theory and the exercises given in this course.

\section{REFERENCES}

1. Gilakjani, A. P. (2016). English Pronunciation Instruction: A Literature Review. International Journal of Research in English Education.

2. Katamba, F. (1989). An Introduction to Phonology. Longman

3. Kelly, G. (2000). How to Teach Pronunciation. Longman.

4. Endahati, N. (2014). Peningkatan Kemampuan Pronunciation Mahasiswa Kelas A1 Semester I Program Studi Pendidikan Bahasa Inggris FKIP UPY TA 2013/2014 Melalui Pendekatan Audiolingual.[Improving Pronunciation Ability of Class A1 Semester I English Education Study Program FKIP UPY Academic Year 2013/2014 Through Audiolingual Approach]: PGRI Univerity

5. Roach, P. (2000). English Phonetics and Phonology: A Practical Course. Cambridge University Press.

6. Faizah, S. (2011). A Practical Guide to Understanding Basic English Phonetics and Phonology. Native Indonesia Press.

7. Yates, L, \& Zielinski, B. (2009). Give It a Go: Teaching Pronunciation to Adults. Sydney, Australia: AMEPRC. Available: in http://www.ameprc.mq.edu.au/resources/classroom resources/

Cite this Article: Ni Luh Ketut Mas Indrawati, Ida Ayu Made Puspani (2021). The Capability of Pronouncing the English

Diphthongs by the English Department Students, Faculty of Humanities, Udayana University. International Journal of Current Science Research and Review, 4(5), 393-400 